\title{
Interdisciplinary analysis of soil acidification hazard and its legacy effects in Lithuania
}

\author{
M. Eidukeviciene ${ }^{1}$, J. Volungevicius ${ }^{2}$, S. Marcinkonis ${ }^{3,5}$, L. Tripolskaja ${ }^{3}$, D. Karcauskiene ${ }^{4}$, M. A. Fullen ${ }^{6}$, and \\ C. A. Booth ${ }^{5}$ \\ ${ }^{1}$ Department of Social Geography, Faculty of Social Sciences, Klaipeda University, Minijos 153, 93185 Klaipeda, Lithuania \\ ${ }^{2}$ Department of Geography and Landscape Management, Vilnius University, M.K. Ciurlionio 21/27, 03001 Vilnius, Lithuania \\ ${ }^{3}$ Voke Branch of the Lithuanian Research Centre for Agriculture and Forestry, Zalioji a.2, Traku Voke, 02232, Vilnius, \\ Lithuania \\ ${ }^{4}$ Vezaiciai Branch of the Lithuanian Research Centre for Agriculture and Forestry, Vezaiciai, Gargzdu 29, 96216, \\ Klaipeda District, Lithuania \\ ${ }^{5}$ School of Applied Sciences, The University of Wolverhampton, Wulfruna Street, Wolverhampton WV1 1LY, UK \\ ${ }^{6}$ School of Engineering and the Built Environment, The University of Wolverhampton, Wulfruna Street, \\ Wolverhampton WV1 1LY, UK
}

Received: 13 May 2010 - Accepted: 28 June 2010 - Published: 9 July 2010

\begin{abstract}
An analysis of factors influencing effective soil acidification management is reported. This analysis was conducted simultaneously at both national and local levels. These investigations were accomplished in three stages: (i) validation of acid soil spatial patterns using systems analysis and geoinformation methods; (ii) spatial statistical analysis of soil $\mathrm{pH}$ diversity using a statistical grid method; and (iii) development of the concept of soil acidity management. Results indicate the national spatial distribution of topsoil reaction is a natural and stable phenomenon related to Quaternary sub-surface deposits. However, secondary effects of topsoil liming are evident in both spatial and temporal soil reaction patterns.
\end{abstract}

\section{Introduction}

A major focus of modern global soil science research is the conservation of soil as a fundamental natural resource, in a healthy and high quality condition, capable of yielding economically-viable high quality crops (Karlen et al., 2003). This focus has encouraged the European Commission to recognise soil protection as a policy priority (COM 179, 2002).

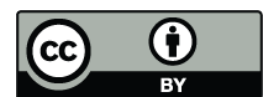

Correspondence to: S. Marcinkonis (saulius.marcinkonis@voke.lzi.lt)
Lithuania is located in the humid zone, where mean annual precipitation $(748 \mathrm{~mm})$ exceeds mean evapotranspiration $(512 \mathrm{~mm})$ (Kilkus et al., 2006) and soil acidification is an ongoing natural process (Bolan et al., 2003). Moreover, acidification is an international soil degradation issue. Thus, research into soil acidification management (SAM) is timely (Eresko, 2005; Ivanov, 2000; Bogdevitch et al., 2005).

SAM is a multifaceted approach utilized by soil science, agro-chemistry, geochemistry and soil geography disciplines. In essence, SAM includes both neutralization of soil acidity and regulation of the acidification of limed soils. The solution depends on a different approach towards the soil as the object of study and the boundaries of anthropogenic effects. A gap has always existed between our knowledge of soil as a natural resource in space and time, and understanding anthropogenic impacts in direct relation to practical solutions.

Experimental investigations of soil acidity management on arable land decreased in most West European and Scandinavian countries several decades ago. Currently, such investigations continue mainly on degraded soils and forest and mountain land-systems (Lundström et al., 2003). In part, this change in focus is because soil is not viewed as a natural amenity, but is used as intermediate media to meet agricultural requirements by the controlled selection and application of agrochemicals to regulate soil acidity. In contrast, in many East and Central European countries, decreases in soil liming and organic fertilizing and associated unbalances in mineral

Published by Copernicus Publications on behalf of the European Geosciences Union. 
fertilizer applications are recurrent problems (Löfgren et al., 1999). With a reduction in agricultural anthropogenic load, agro-ecosystems return to their primeval state through selfregulation. Furthermore, artificially-formed field boundaries are being removed (Rusanov, 2003), causing huge diversity in soil properties even at small scales, where natural soil properties define soil acidity characteristics.

Valuable SAM experience has been gained in Lithuania. In the mid-1960s, acid soils ( $\mathrm{pH}$ in $\mathrm{KCl} \leq 5.5$ ) covered $41 \%$ of agricultural land, which has a national territory of $11660 \mathrm{~km}^{2}$. In some Western and Eastern Lithuanian administrative districts, acid soils covered 70-93\% (Savickas, 1973). Following the introduction of large-scale agricultural technologies (1965-1990) the extent of acid soils was successfully decreased to $19 \%$ nationally and to 27 and $29 \%$ in Western and Eastern Lithuania, respectively. It succeeded due to intensive long-term liming, with applications of dust limestone to 160000-200 000 hectares per year from 1976 . However, as a result of political and economic changes in Lithuania since 1991 and the removal of state support, the extent of liming decreased, falling from 14400 to 4000 hectares per year between 1993 and 1996. Since 1997, the liming of acid soils has virtually ceased, except on large farms and so soil acidification has accelerated (Mazvila et al., 2004).

To date, the most recent notable achievements in spatial soil acidification research have been in Hungary, Poland, Denmark and Lithuania, where due to periodic soil surveys the databases of national soil reaction data and agrochemical information are collated and soil reaction maps produced (Grybauskas, 1978; Motowicka-Terelak, 1985; Kern, 1987; Madsen and Munk, 1987; Varallyay et al., 1989). These provide a scientific background for developing theories of soil acidification prognosis (Eidukeviciene et al., 2006, 2007; Volungevicius et al., 2006), and the principal mechanism for the interaction of factors determining general spatial regularities of soil pH (Eidukeviciene et al., 2007).

The purpose of this study is to investigate interactions between spatial soil acidity patterns and anthropogenic activities over half a century ( $\sim 1950-$ present). This has assisted the development of concepts of soil reaction management employing modern GIS methods.

\section{Methods}

\subsection{Site, soil characteristics and sampling}

Lithuania lies within the area of Pleistocene European Continental glaciation, in the north-west of the East European lowland plain, near the maximum extent of the last glaciation. The topography and associated deposits were formed by the last glaciation (Würm, Weichsel, Vistula, Valdaj). The main soil parent materials are Quaternary deposits, with prevailing glacial till sandy loam, glacio-fluvial sands, glaciolacustrine silty loam and clay. Albeluvisols are the most common upland soils, while Luvisols prevail on upland slopes (Soil Atlas of Europe, 2005).

A system analysis was developed to investigate natural and anthropogenic factors controlling soil reaction, on an interdisciplinary basis and integrating information on pedology, geology, geography and soil agro-chemistry (Fig. 1). Research was conducted at national and local levels, using a database developed over the last 50 years. At national level, agro-chemical agricultural soil survey data from 1964-2004 were used. These data portray the distribution of acid soils in space and time. At local level, data were abstracted from long-term soil liming field experiments conducted during the period 1949-2006. These data are from Lithuanian Institute of Agriculture research stations in Western and Eastern Lithuania (Vezaiciai and Voke Branches, respectively). The data in Western Lithuania represent moraine deposits (till) Albeluvisols. In Eastern Lithuania, soils are glacio-fluvial Arenosols and Luvisols (Soil Atlas of Europe 2005).

The research has been conducted in three stages:

1. Substantiation of acid soils spatial patterns in Lithuania.

2. Spatial statistical analysis of soil $\mathrm{pH}$ diversity.

3. Development of the concept of soil reaction management.

Spatial patterns of acid soils in Lithuania were investigated using system analysis and GIS methods. Performing a spatial multilayer correlation, using GIS, the transformation and coordination of geographical information against the LKS-94 co-ordinate system have been achieved using this methodology. Maps of acidic soils (Savickas, 1973), agricultural land $\mathrm{pH}$ (Grybauskas, 1978), soil liming priorities (Eidukeviciene, 1993), depth to carbonates (Eidukeviciene and Kudaba, 1976) and soil granulometric composition (Volungevicius et al., 2006) have been compared (Fig. 2).

Spatial statistical analysis of soil $\mathrm{pH}$ was carried out on the basis of a modified agricultural land $\mathrm{pH}$ map (Eidukeviciene et al., 2006), which shows the distribution of topsoil $(0-20 \mathrm{~cm}$ depth $) \mathrm{pH}$ values for all Lithuania. For statistical analysis of soil $\mathrm{pH}$ diversity, a statistical grid method (i.e. $2 \times 2 \mathrm{~km}, 4 \mathrm{~km}^{2}$ ) was used, generating a database of 16695 cells. These data were abstracted from agricultural survey data, with one sample per 2-5 ha, depending on landscape variability (Matusevicius, 2005). After Lithuania had been divided into grids, the diversity of soil $\mathrm{pH}$ (number of different $\mathrm{pH}$ value contours) was evaluated. The soil $\mathrm{pH}$ in Lithuania was expressed in diversity points (corresponding to the number of different $\mathrm{pH}$ contours). The diversity in Lithuanian soil $\mathrm{pH}$ spatial structure is grouped into five index categories: very uniform (index 1-2), uniform (index 3), rather diverse (index 4), diverse (index 5-6) and very diverse (index 7-11). The selection of intervals was related to the binomial distribution structure of the data set. According to the standard deviation of the diversity point from the mean (point 2), the soil pH diversity map was compiled (Fig. 3). 


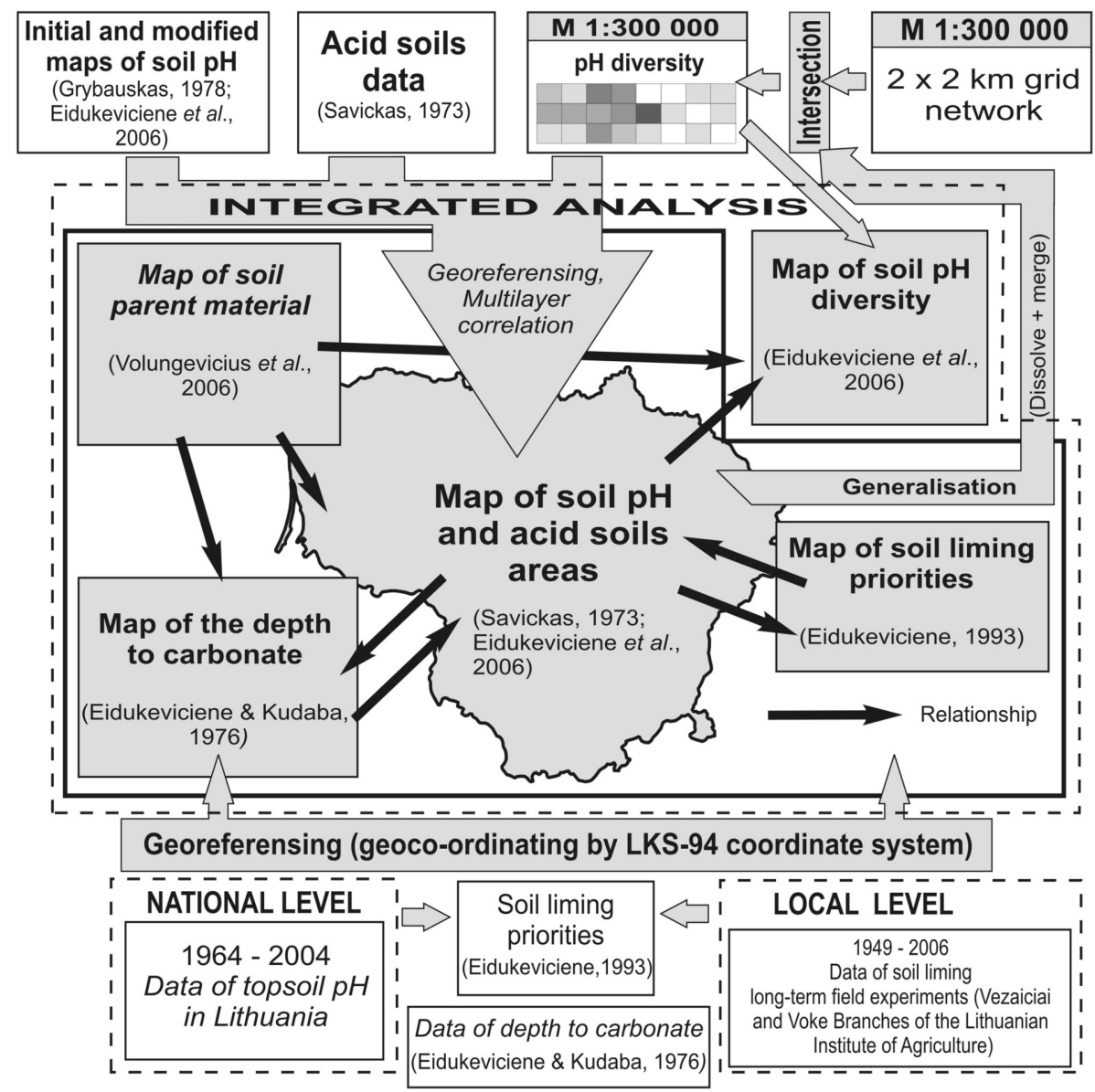

Fig. 1. Methodological scheme of the research.

Changes of the main soil acidity indices ( $\mathrm{pH}$ and mobile $\mathrm{Al}$ ) in the entire soil profile under the impact of soil liming have been evaluated from long-term field experiments of soil liming. The liming concept was to apply the amount of lime required to neutralize the soil hydrolytic (potential) acidity (HAC), which was extractable with a neutral unbuffered solution such as $\mathrm{KCl}$. The amount of lime required to neutralize $\mathrm{HAC}$ is given by the following equation:

Metric tons $\mathrm{CaCO}_{3}$ per hectare $=0.15 \times \mathrm{HAC}\left(\mathrm{meq} \mathrm{kg}{ }^{-1}\right)(1)$

Indices of soil $\mathrm{pH}$, using both initial acid soil and various limed soils, were developed based on analysis of 27 individual soil profiles in Voke and Vezaiciai.

\subsection{Laboratory methods}

Soil $\mathrm{pH}$ was measured potentiometrically after equilibration with $1.0 \mathrm{~N} \mathrm{KCl}$ solution. Mobile Al was determined by the Sokolov method (Yagodin et al., 1987). After extraction with $1.0 \mathrm{~N} \mathrm{KCl}$ solution, a suitable aliquot was titrated with $0.01 \mathrm{~N}$ $\mathrm{NaOH}$ using phenolphthalein as the indicator for the determination of total exchangeable acidity $(\mathrm{H}+, \mathrm{Al} 3+)$. In a second aliquot, the acidity from $\mathrm{H}+$-ions was determined by the same titration, after precipitation of the Al3+-ions with 3.5\% $\mathrm{NaF}$. The quantity of mobile $\mathrm{Al}$ was calculated as the difference between the first and second titration. Laboratory data were analysed using Analysis of Variance (ANOVA) (Little and Hills, 1978).

\section{Results}

Conventional liming for over half a century has not abolished national topsoil reaction diversity. Soil reaction (both topsoil and subsoil) at national level and distribution of acid soil areas are fundamentally stable natural phenomena. Outlines of areas of acid soils limed once or twice repeat initial acid soils areas. A trend towards soil acidification is evident in primary acid soil areas, where the extent of liming in the last 15 years has decreased and then stopped. Soil $\mathrm{pH}$ diversity in these areas is both low and high. Low soil $\mathrm{pH}$ diversity prevails only in specific areas of relatively mature relief, of mainly Middle Pleistocene age (Haplic Albeluvisols, Dystric Planosols and Dystric Luvisols with depth to carbonates $>1.5 \mathrm{~m}$ ). On areas of initial non-acid soils, which 


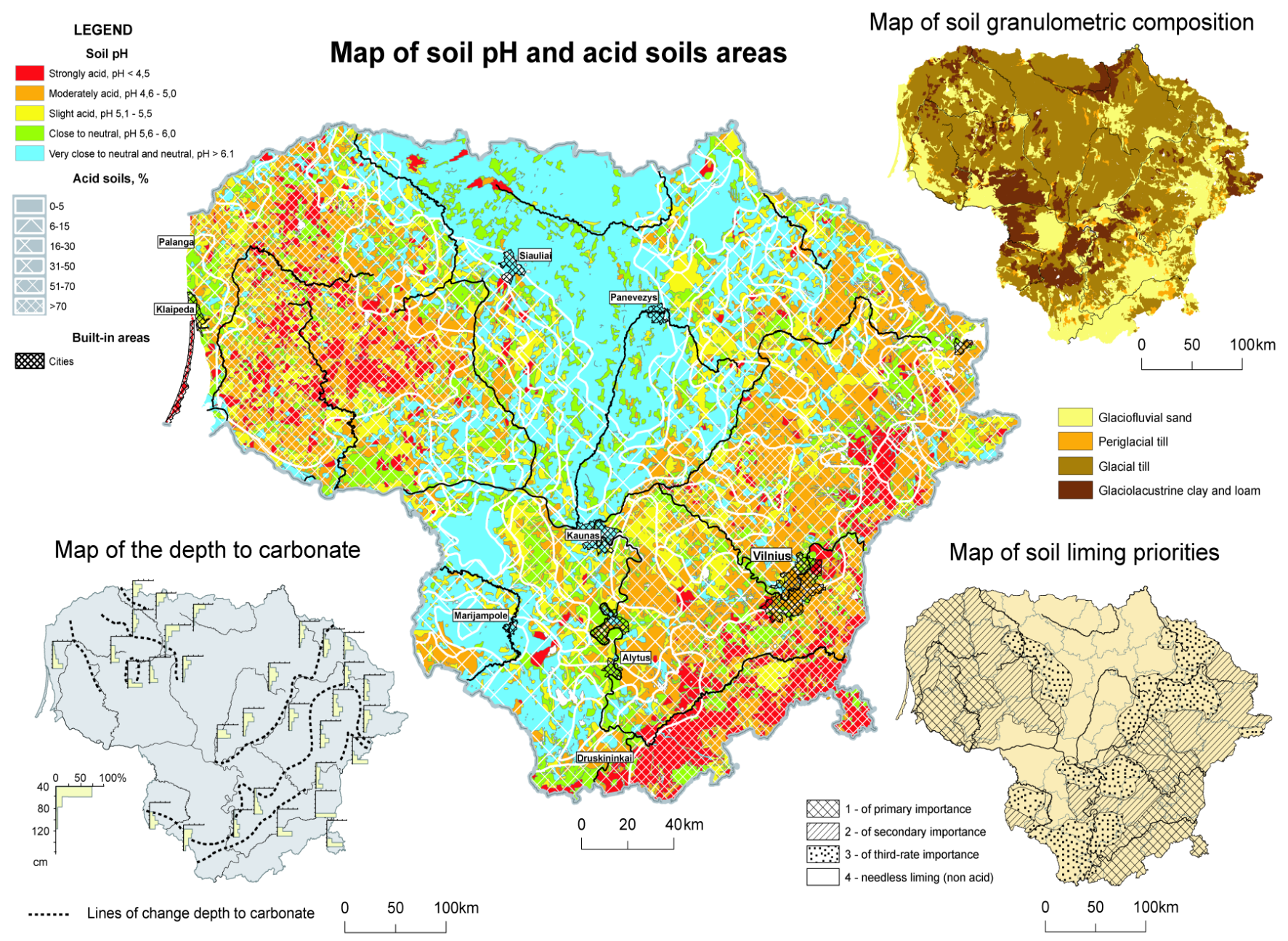

Fig. 2. National map of soil $\mathrm{pH}$.

do not require liming (Gleyic Cambisols, Eutric Cambisols and Calcic Luvisols, depth to carbonates $0.4-0.5 \mathrm{~m}$ ), soil $\mathrm{pH}$ diversity is low. Thus, there are marked spatial variations in liming requirements and priorities need to be identified. Acidification mainly occurs in moraine loam (till) Albeluvisols (Western and Eastern Lithuania), glacio-fluvial sand Arenosols (Eastern Lithuania) and moraine sandy loam Luvisols (South-Eastern Lithuania). Lime applications have ceased on these soils and, consequently, soil acidification is increasing in acid soil territories in Western and Eastern Lithuania, in Albeluvisols, Arenosols and Luvisols, which have a thick acid reaction layer $(\sim 1.5 \mathrm{~m})$.

\subsection{Soil acidity neutralization}

Experiments at local level prove that hydrolytic acidity is the main primary liming requirement indicator on moraine sandy loam Albeluvisols and glacio-fluvial sand Luvisols and Arenosols. The most effective means of neutralization is primary liming (single application) at one rate according to soil hydrolytic acidity. The main acidity indexes in the Albeluvisols topsoil reveal: $\mathrm{pH}$ changes from 4.4-6.6 and mobile $\mathrm{Al}$ changes from toxic to plants $\left(78 \mathrm{mg} \mathrm{kg}^{-1}\right)$ to nontoxic $\left(4 \mathrm{mg} \mathrm{kg}^{-1}\right)$ (Fig. 4). One rate (6.6-7.8 $\left.\mathrm{tha}^{-1} \mathrm{CaCO}_{3}\right)$ of lime remains effective (i.e. until soil reaches $\mathrm{pH} 5.5$ ) in moraine loam for $\sim 10$ years, while in glacio-fluvial sandy soil one rate of lime $\left(6.5 \mathrm{tha}^{-1} \mathrm{CaCO}_{3}\right)$ is effective (until soil reaches $\mathrm{pH}$ 5.3) for only 5 years (Fig. 4). Soil pH returns quicker to initial levels in sandy soils than in moraine loams, after 20-22 and 23-28 years, respectively.

Mobile $\mathrm{Al}$ was affected by liming more than $\mathrm{pH}$. The amount of mobile $\mathrm{Al}$ in soil limed with one rate does not exceed the concentration tolerance of plants $\left(20 \mathrm{mg} \mathrm{kg}^{-1}\right)$ in glacio-fluvial sandy soil for 12 years and in moraine loam soil for 28 years. Mobile $\mathrm{Al}$ in sandy soil increases in the range $\leq 24 \mathrm{mg} \mathrm{kg}^{-1}$ for 15 years and continues to increase slightly, but even after 34 years, the concentration of mobile Al was half $\left(34 \mathrm{mg} \mathrm{kg}^{-1}\right)$ of the initial $66 \mathrm{mg} \mathrm{kg}^{-1}$. In contrast, in loamy soil, mobile $\mathrm{Al}$ increases $\left(\leq 30-35 \mathrm{mg} \mathrm{kg}^{-1}\right)$ over 35 years and returns to the initial level in $\geq 50$ years. 


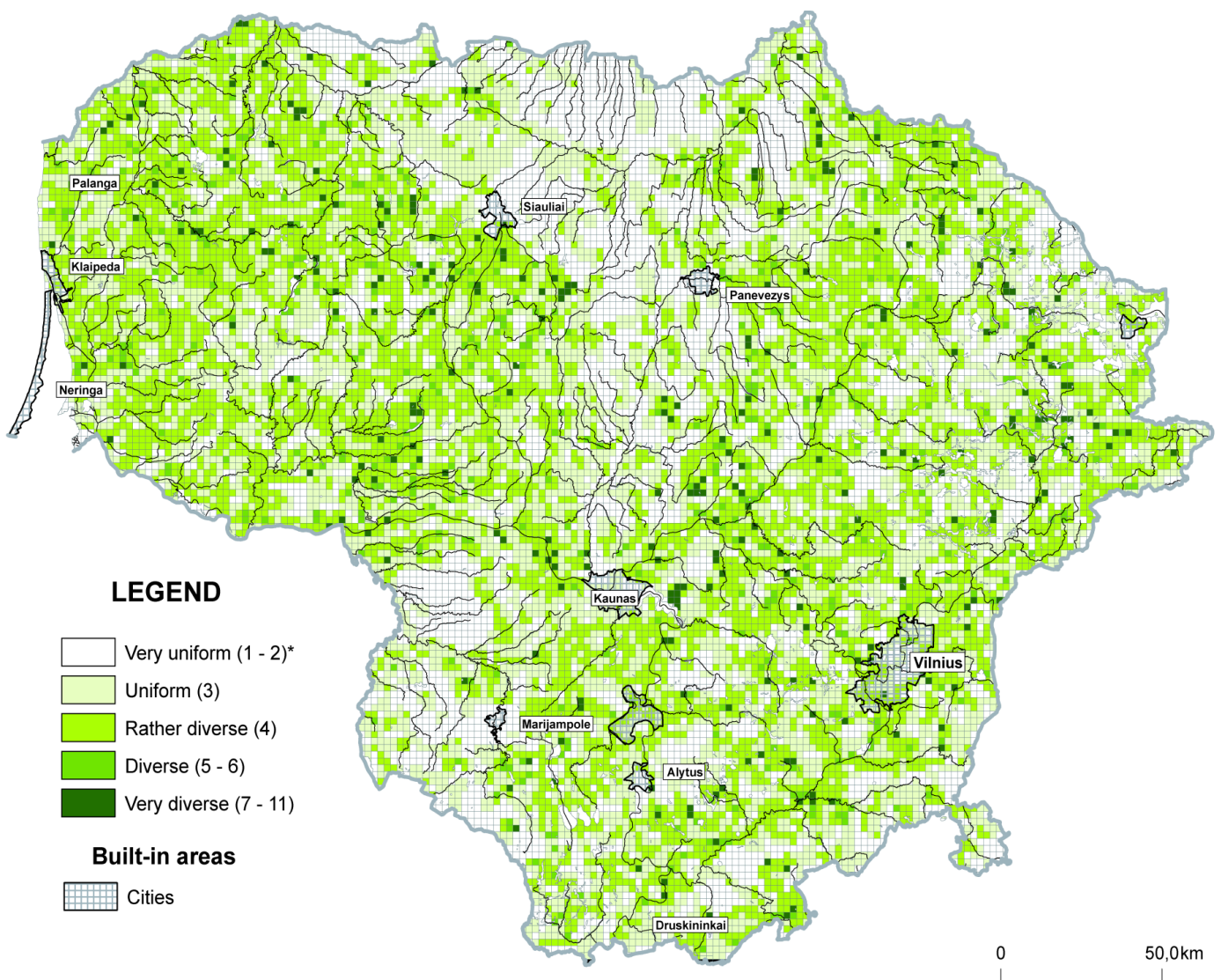

Fig. 3. Soil pH diversity in Lithuania.

One rate of lime fertilizers influences acidity indexes in moraine loam even more slowly (35 years) when coarser lime fertilizers, such as tufa (calcareous sediments) or carbonate loam, are used (Ozeraitiene et al., 2006). High fluctuations of mobile $\mathrm{Al}$ concentration (from 62 to $110 \mathrm{mg} \mathrm{kg}^{-1}$ ) in moraine loam soil on unlimed treatment possibly resulted from acid precipitation associated with the pollutionintensive industrial period (1960s).

In summary, it is possible to assert that one rate of primary liming according to hydrolytic acidity, essentially influences soil $\mathrm{pH}$ up to 10 years and mobile $\mathrm{Al}$ for $10-35$ years. After primary liming, glacio-fluvial sandy soil acidifies faster than moraine loam.

\subsection{Management of soil acidity in limed soils}

Soil acidification proceeds at different rates: in the initial 714 years after liming $\mathrm{pH}$ decreases faster $(0.1-0.3 \mathrm{pH}$ units per year), but later the process slows down. Acidification and consequent $\mathrm{Al}$ release are suppressed for $>30$ years in sandy and $\sim 50$ in loamy soils (Fig. 4). To control soil reaction, repeated and periodic liming cycles and rates on the background of primary liming with one rate should be applied to prevent $\mathrm{pH}$ decreased and increased concentrations of toxic Al.
In moraine loamy soil, the recommended $\mathrm{pH}$ level of 5.66.2 for plants in the topsoil is achieved on the periodic third or fourth liming using a 50-year liming system (primary $\times 1$ rate + repeated $\times 0.5$ rate + periodic $\times 1$ rate every $3-4$ years). Soil $\mathrm{pH}>6.9$ can be sustained by repeating periodic liming after application five or six. Periodic liming of glacio-fluvial sandy soil with one rate of dust limestone every 10 years maintains topsoil $\mathrm{pH}$ at 5.2-5.4. During periodic liming, mobile $\mathrm{Al}$ changes into immobile forms in loams or its concentrations are non-toxic (1.6-2.2 $\mathrm{mg} \mathrm{kg}^{-1}$ in sand) (Fig. 5).

Periodic liming at one rate, followed by different intensities (every 3-4 years and every 10 years) repeated over two decades changes acid soil characteristics both in topsoil and the whole profile to $\leq 100 \mathrm{~cm}$ depth (Eidukeviciene et al., 2001). In moraine loam, maximum changes of acidity indexes (mobile $\mathrm{Al}$ from $78 \mathrm{mg} \mathrm{kg}^{-1}$ to immobile forms and $\mathrm{pH}$ from 4.0 to 6.5-6.9) are in topsoil. In EB horizons at 30$50 \mathrm{~cm}$, changes are less (mobile $\mathrm{Al}$ from 230 to $80 \mathrm{mg} \mathrm{kg}^{-1}$ and $\mathrm{pH}$ from 3.9 to 5.0-6.2) and changes are insignificant at $50-100 \mathrm{~cm}$ depth when soil is limed at $\times 1$ rate every $3-4$ years. Liming of glacio-fluvial sand with $\times 1$ rate every 10 years gives maximum effect on the acidity indexes throughout the profile $(\leq 100 \mathrm{~cm})$. Mobile $\mathrm{Al}$ changes from 37 to $10 \mathrm{mg} \mathrm{kg}^{-1}$ and $\mathrm{pH}$ from 4.2 to 5.0-5.5. Liming has influenced changes even up to $60 \mathrm{~cm}$. At greater depths, changes 



Glaciofluvial sand

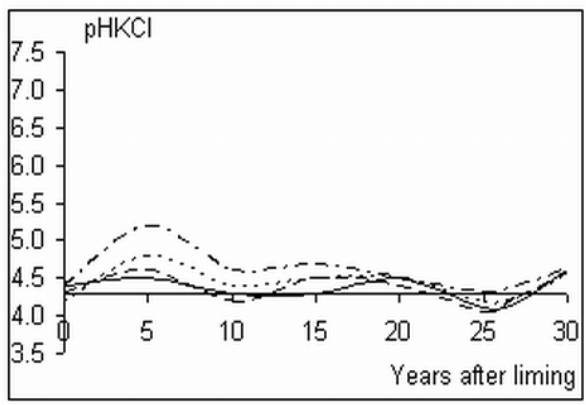

U Unlimed

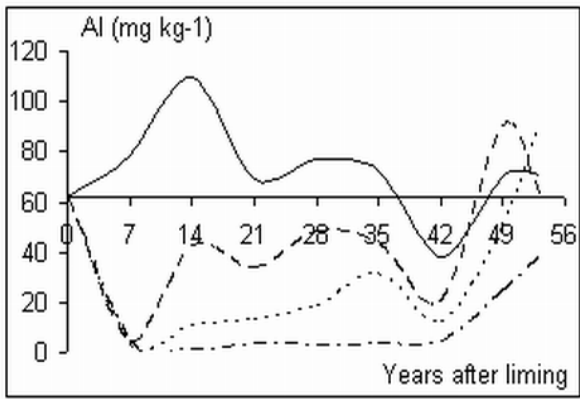

$\cdots \cdots 1.0$ rate $\quad-\cdot-\cdots 2.0$ rate

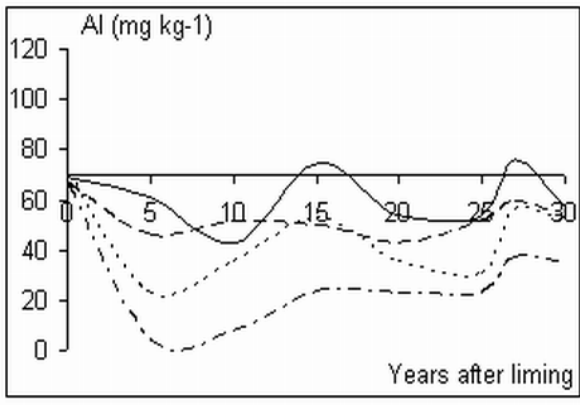

$\cdots \cdots .0 .5$ rates $\quad-\cdot-\cdot-1.0$ rate

Fig. 4. The effect of primary liming on changes in soil acidity indexes.

are related to the effect of carbonate horizons with effervescence having present at $0.8-1.0 \mathrm{~m}$ (Eidukeviciene et al., 2001).

Recent findings in forest soils suggest surface horizons are more sensitive to external influences than deeper soils, where soil reaction is more closely related to soil genetic processes (Boruvka et al., 2007). The presented evidence suggests that liming cannot stop or fundamentally change the prevailing soil processes. However, it is possible to maintain $\mathrm{pH}$ values at a certain level by using a long-term liming system (primary, repeated and periodic). After primary liming with recommended $\times 1$ rate, glacio-fluvial sandy soil acidified faster than moraine loam. Despite that, long term systematic liming on glacio-fluvial sand is very effective. Even periodic liming at $\times 1$ rate every 10 years sustains low acidity reaction and maintains mobile $\mathrm{Al}$ below toxic concentrations to $\leq 100 \mathrm{~cm}$ depth. Yet, in moraine loam soil, three times more intense liming ( $\times 1$ rate every 3-4 years) maintains neutral reaction and immobilizes $\mathrm{Al}$ only in the topsoil and decreases its concentration (from $300-150 \mathrm{mg} \mathrm{kg}^{-1}$ ) in EB horizons to $50 \mathrm{~cm}$ depth.

System analysis of 50-years of Lithuanian soil reaction data show that the whole soil system in terms of its thickness and stratigraphy within the topsoil, subsoil and parent materials of Quaternary deposits, plays collective and interacting roles. Thus, these components should not be considered in isolation. The effect of human economic activity on topsoil in time and space is evident, although the consequences are less important as natural background effects. Both soil processes and the effectiveness of economic activities are subject to natural spatial patterns.

\section{Discussion}

Awareness of soil acidification hazard issues and timely intervention are the tools that farmers and land managers can use to prevent this land degradation process. Liming at one rate (according to hydrolytic soil acidity) sustains optimum soil $\mathrm{pH}$ levels for plant growth. However, we propose additional hypothetical levels: minimal primary liming at $\times 0.5$ rate and maximum system periodic liming at $\times 2$ rate every 3-4 years. However, three problems exist: (i) degradation of minimally-limed soil; (ii) degradation of over-limed soil and (iii) substantiation of sustainable maintenance of liming to maintain optimum soil $\mathrm{pH}$.

The problem of cultivation of acid soils four decades ago was based on limited (13-years) experience of long-term field experiments at Vezaiciai, Western Lithuania. Then it was considered that it would be possible to neutralize soil acidity more effectively with two rates of lime application. It was 
Moraine loam

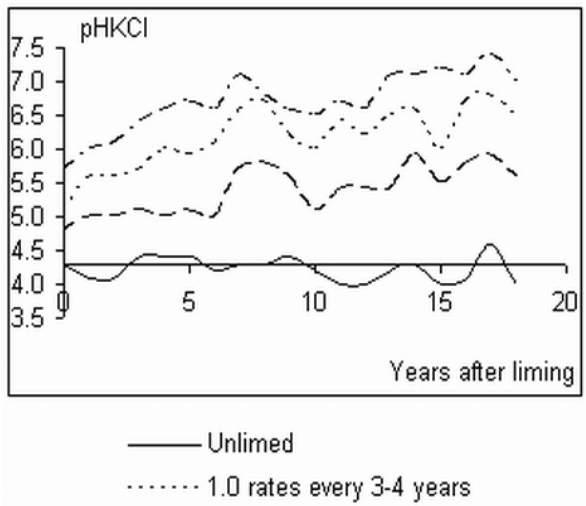

Glaciofluvial sand

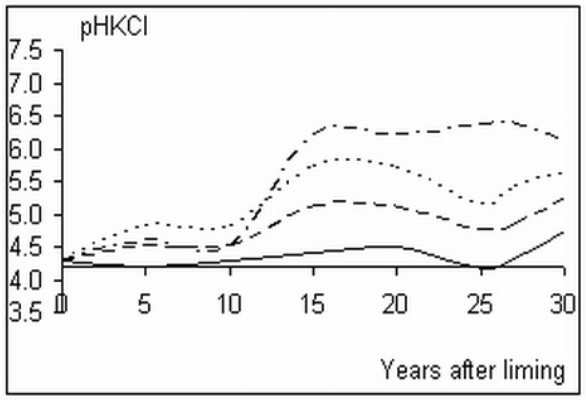

Unlimed $\quad----0.5$ rates every 10 years

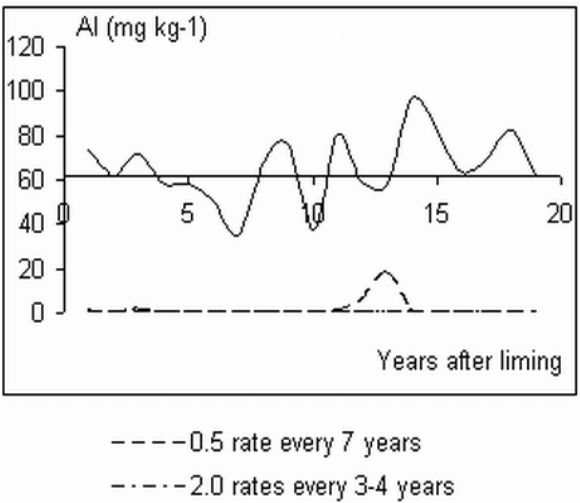

$-\cdot-\cdot-2.0$ rates every $3-4$ years

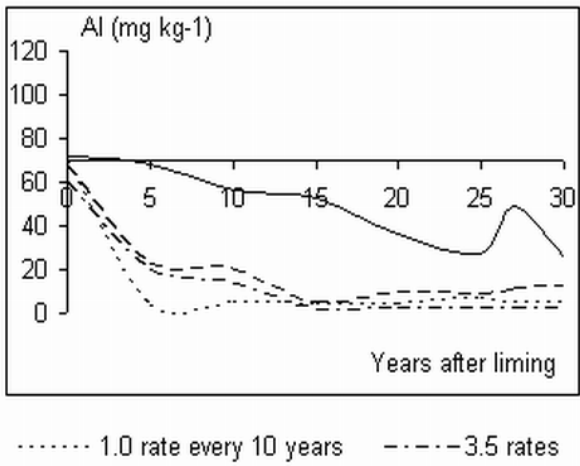

Fig. 5. The effect of periodic liming by different rates of dust limestone on the change of soil acidity indexes.

also hoped that periodic liming would neutralize deeper horizons and decrease acidification rates. However, even then, it was understood that soil cannot be cultivated immediately (Galvydyte, 1968). The 50-year results of long-term liming experiments show these expectations were correct. Although soil researchers could not predict modern problems, these issues did progressively appear. Permanent arable land use has led to the degradation of soil physico-chemical properties. Acidification of permanent arable topsoils is accelerated by the application of fertilizers and intensive leaching of upper soil horizons due to cultivation (Szilassi et al., 2006).

Analysis of Lithuanian soils $\mathrm{pH}$ dynamics over half a century under the influence of hypothetical minimal liming level with primary $\times 0.5$ rate, completed 50 years ago, shows soil acidity neutralization must be an uninterrupted process. Once soil looses its chemical balance it is less resistant to acidification than initially acidic soil. Currently, acidification on soil limed at $\mathrm{x} 0.5$ rate $\left(3.3 \mathrm{tha}^{-1} \mathrm{CaCO}_{3}\right) 50$ years ago is greater $(0.1-0.3 \mathrm{pH}$ units less) than on the initial acid soil (Fig. 4).

Analysis of $\mathrm{pH}$ dynamics over half a century under the influence of hypothetical maximum liming level with two rates every 3-4 years according to initial hydrolytic soil acidity is a strategy, which has been applied for some 20 years. Data shows that it results in topsoil $\mathrm{pH}$ values of 7.2-7.4 and
$\mathrm{pH}$ values of 5.2-5.6 in subsoil to $50 \mathrm{~cm}$ depth. However, such notable changes in moraine loam soil $\mathrm{pH}$ values cause more intense eluviations of colloidal particles. This results in the decrease of topsoil clay fraction by $2-4 \%$ in intensively limed soil compared with unlimed and cause the decrease of soil buffering capacity and faster acidification after liming (Ozeraitiene et al., 2006). From the perspective of soil protection, such intense liming is unjustified and the combinations of intense liming (to maintain soil $\mathrm{pH} \sim 6.7$ ) and excess mineral fertilization $(\times 3 \mathrm{NPK})$ is potentially damaging because it cause the decrease of clay fraction and organic colloidal particles in moraine loam topsoil (Bernotas et al., 2005). Unfavourable consequences of liming include increasing carbon mineralization and nitrate leaching (Hüttle and Schneider, 1998). On the other hand, organic fertilization decreases soil acidification, as the acidifying effect of added ammonium nitrogen is partly compensated by $\mathrm{Ca}$ inputs with superphosphate.

Complex soil investigations (agrochemical, physical and microbiological), based on 30-years of liming on moraine loamy soil, show the optimum $\mathrm{pH}$ level in moraine loam soils in Western Lithuania is 5.7-6.2, which is achieved by systematic liming with $\times 0.5$ rates $\left(3.8 \mathrm{tha}^{-1} \mathrm{CaCO}_{3}\right)$ every 7 years or $2.5-5.5 \mathrm{tha}^{-1}$ every 5 years. This necessitates both maintenance liming and the use of the index to determine 
lime requirements. Liming concepts are regularly revised and improved in many countries (Tsakelidou, 1995; Matula and Pechova, 2002; Sikora, 2006). In Scandinavia, it is used to determine the rate of lime, not according to $\mathrm{pH}$, but the ratio of cations or nutrient balance data (Wiklander, 1986; Nykänen, 1998).

In Lithuania, a unanimous opinion is not yet agreed. There have been suggestions to use $\mathrm{pH}$, hydrolytic acidity, mobile $\mathrm{Al}$ concentration or cation exchange capacity (CEC), depending on the direction of agricultural policy. In Lithuania, there remains a gap between soil liming theory and solving national soil liming problems. In recent years, the influence of socio-economic conditions has increased this knowledge gap.

It has been acknowledged that soil acidification differences in Lithuania, in the absence of liming, are essentially dependent on the genetic diversity of soil acidity in soil profile. Therefore, the concept of differentiated liming is proposed. This prioritizes so-called originally acid soil areas that were present before intensive liming.

\section{Conclusions}

Spatial patterns of topsoil $\mathrm{pH}$ in Lithuania are fundamentally controlled by soil parent material. The $\mathrm{pH}$ spatial structure of topsoils, limed once or twice, basically echoes initial soil reaction conditions. Topsoil, subsoil and parent material collectively influence soil reaction and should not be treated as separate components. The effect of economic activities on agricultural topsoil in space and time is evident, although the consequences are not as important as natural background effects. Natural and economic processes affect soil in specific areas and the effectiveness of management activities is strongly influenced by pedogenic processes.

In moraine loam, greatest changes of acidity indexes (immobilizing of $\mathrm{Al}$ and $\mathrm{pH}$ increase from 4.0 to 6.5-6.9) are in topsoil. In EB horizons at $30-50 \mathrm{~cm}$ changes are marked less (mobile $\mathrm{Al}$ from 230 to $80 \mathrm{mg} \mathrm{kg}^{-1}$ and $\mathrm{pH}$ from 3.9 to 5.0 6.2) and changes are insignificant at $50-100 \mathrm{~cm}$ depth when soil is limed at $\times 1$ rate every $3-4$ years. Liming of glaciofluvial sand with $\times 1$ rate every 10 years gives maximum effect on the acidity indexes throughout the profile $(\leq 100 \mathrm{~cm})$. Mobile $\mathrm{Al}$ changes from 37 to $10 \mathrm{mg} \mathrm{kg}^{-1}$ and $\mathrm{pH}$ from 4.2 to 5.0-5.5.

Acknowledgements. We thank J. Savickas and J. Grybauskas for their deep theoretical foundation of soil liming as a national problem and thorough summary of the first national soil $\mathrm{pH}$ investigations in Lithuania. Saulius Marcinkonis gratefully acknowledges the receipt of a Lady Wulfrun Visiting Research Fellowship from the School of Engineering and the Built Environment at the University of Wolverhampton, UK.

Edited by: R. Lasaponara

Reviewed by: I. Bogdevitch and another anonymous referee

\section{References}

Bernotas, S., Ozeraitiene, D., and Koncius, D.: Analysis of anthropogenic factors influencing the process of soil acidification, Zemès ukio mokslai, 2, 22-31, 2005 (in Lithuanian, with English summary).

Bogdevitch, I., Smigelskaya, I., Germanovitch, T., Konasenko, Y., and Kalenik, G.: Dinamika plodorodija pakhotnykh pochv Belorusii, Pochvovedenie i agrokhimija, (Soil fertility dynamics of arable soil in Belarus, Soil Sci. Agrochemistry), 1, 197-173, 2005 (in Russian).

Bolan, N. S., Adriano, D. C., and Curtin, D.: Soil acidification and liming interactions with nutrient and heavy metal transformation and bioavailability, Adv. Agronomy, 78, 215-272, 2003.

Boruvka, L., Mladkova, L., Penizek, V., Drabek, O., and Vasat, R.: Forest soil acidification assessment using principal component analysis and geostatistics, Geoderma, 140, 374-382, 2007.

COM. 2002: Communication from the Commission to the Council, the European Parliament, the Economic and Social Committee and the Committee of the Regions Towards a Thematic Strategy for Soil Protection, Commission of the European Communities, Brussels, 2002.

Eidukeviciene, M.: Geokhimicheskoe i geograficheskoe obosnovanie optimizirovanija izvestkovanija kislykh pochv Litvy, Dissertacija gabillitirovannogo doktora geograficheskikh nauk (Geochemical and geographical validation of optimalization of liming acid soils in Lithuania. Doctor habilitatis thesis), Vilnius, 99 p., 1993 (in Russian, with English summary).

Eidukeviciene, M. and Kudaba, C.: Glubina vymyvanija karbonatov kak kriterij vydelenija raznovozrastnykh gliacigennykh kompleksov na territorii Litvy (Depth to carbonates as criteria of glacial complexes in the territory of Lithuania), Geografija Geologija, 13, 31-35, 1976 (in Russian, with English summary).

Eidukeviciene, M., Ozheraitiene, D. J., Tripolskaja, L. N., and Marcinkonis, S. I.: The effect of long-term liming on the chemical properties of Lithuanian soils, Eurasian Soil Science, 34(9), 999-1005, 2001.

Eidukeviciene, M., Volungevicius, J., and Prapiestiene, R.: Substantiation of soil $\mathrm{pH}$ spatial regularities in Lithuania, Geografija, 42, 8-14, 2006 (in Lithuanian, with English summary).

Eidukeviciene, M., Ozeraitiene, D., Tripolskaja, L., and Volungevicius, J.: Change of soil $\mathrm{pH}$ in the territory of Lithuania: spatial and temporal analysis, Zemès ukio mokslai, 4(3), 1-8, 2007.

Eresko, M.: Bufernost' k podkisleniju dernovo-podzolistykh pochv razlichnogo granulometricheskogo sostava i stepeni uvlazhnenija, Pochvovedenie i agrokhimija. (Buffering against acidification of various granulometric composition and degree of hydromorphism of soddy podzolic soil, Soil Science \& Agrochemistry), 1, 96-99, 2005 (in Russian).

Galvydyte, D.: Questions on the cultivation of Lithuanian soils, Annales Geographicae - The Geographical Yearbook, 9, 37-51, 1968 (in Lithuanian, with German summary).

Grybauskas, J.: Kislotnost' pochv i dozy izvesti po pHKCl v Litovskojj SSR, Avtoreferat dissertacii na soiskanie uchenojj stepeni kandidata sel'skokhozjajjstvenykh nauk (Soil pH and rates of liming according $\mathrm{pHKCl}$ in Lithuania, $\mathrm{PhD}$ Thesis), Centre of Agrochemical Research, Kaunas, 20 pp., 1978 (in Russian).

Hüttle, R. F. and Schneider, B. U.: Forest ecosystem degradation and rehabilitation, Ecological Engineering, 10, 19-31, 1998.

Ivanov, A.: Nekotorye zakonomernosti izmenenija kislotno- 
osnovnogo sostojanija dernovo-podzolistykh legkosuglinistykh pochv pri sel'skokhozjajjstvennom ispol'zovanii. Agrokhimija (Some regularities of acid-base state of sandy loam soddy podzolic soils under agricultural use, Agrochemija), 10, 28-33, 2000 (in Russian).

Karlen, D. L., Ditzler, C. A., and Andrews, S. S.: Soil quality: why and how?, Geoderma, 114, 145-156, 2003.

Kern, H.: Acidity and $\mathrm{CaCO}_{3}$ content in soils of the agricultural areas of Poland, Zeszyty problemove postepow nauk rolniczych, 344, 45-58, 1987.

Kilkus, K., Staras, A., Rimkus, E., and Valiuskevicius, G.: Changes in water balance structure of Lithuanian rivers under different climate change scenarios, Environmental Research, Engineering and Management, 36, 3-10, 2006.

Little, T. M. and Hills, F. J.: Agricultural Experimentation: Design and Analysis, John Wiley and Sons, New York, NY, 368 pp, 1978.

Löfgren, S., Gustafson, A., Steineck, S., and Stålnacke, P.: Agricultural development and nutrient flows in the Baltic States and Sweden after 1988, Ambio, 28, 320-327, 1999.

Lundström, U. S., Bain, D. C., Taylor, A. F. S., and van Hees, P. A. W.: Effects of acidification and its mitigation with lime and wood ash on forest soil processes: A Review, Water, Air Soil Pollut.: Focus, 3, 5-28, 2003.

Madsen, H. B. and Munk, J.: The influence of texture, soil depth and geology on $\mathrm{pH}$ in farmland soils, Acta Agriculturae Scandinavica, 37, 407-418, 1987.

Matula, J. and Pechova, M.: A simplified approach to liming and its evaluation. Communications in Soil Science and Plant Analysis, 33, 2989-3006, 2002.

Matusevicius, K.: Lietuvos agrochemine tarnyba 1965-2005, Akademija, 197 pp., 2005 (in Lithuanian, with English summary).

Mazvila, J., Adomaitis, T., and Eitminavicius, L.: Changes in the acidity of Lithuanian soils as affected of non-liming, Agriculture, 4, 3-20, 2004 (in Lithuanian, with English summary).

Motowicka-Terelak, T.: Influence of the geological origin of parent rocks and the granulometric composition on the acidification and the results of liming of soils, Soil Sci. Annual, 36, 151-156, 1985.
Nykanen, A.: Effects of liming on exchangeable calcium and magnesium content of the soil, MTT, 19 pp., 1998 (in Finnish, with English summary).

Ozeraitiene, D., Pleseviciene, A. K., and Gipiskis, V.: Duration of action of different lime fertilizers and their effect on soil properties and yield of crop rotation crops, Zemdirbyste-Agriculture, 1, 3-21, 2006 (in Lithuanian, with English summary).

Rusanov, A. M.: Prospects for conserving and restoring the properties and ecological functions of arable soils, Russian Journal of Ecology, 34, 10-15, 2003.

Savickas, J.: Plots of acid soils in Lithuania and its characteristics, in: Mineral fertilizers, Mintis Press, Vilnius, 291 pp., 1973 (in Lithuanian).

Sikora, F. J.: A buffer that mimics the SMP buffer for determining lime requirement of soil, Soil Sci. Soc. Am. J., 70, 474-486, 2006.

Soil Atlas of Europe: European Soil Bureau Network European Commission. Luxembourg: Office for Official Publications of the European Communities, 128 pp, 2005.

Szilassi, P., Jordan, G., van Rompaey, A., and Csillag, G.: Impacts of historical land use changes on erosion and agricultural soil properties in the Kali Basin at Lake Balaton, Hungary, Catena, 68, 96-108, 2006.

Tsakelidou, R.: Comparison of lime requirement methods on acid soils of northern Greece, Communications in Soil Science and Plant Analysis, 3-4, 541-551, 1995.

Varallyay, G., Redly, M., and Muranyj, A.: Map of the susceptibility of soils to acidification in Hungary. Ecological impact of acidification, in: Environmental threats to forest and other natural ecosystems, pp. 79-94, Hungarian Academy of Sciences, Budapest, Hungary, 1989.

Volungevicius, J., Eidukeviciene, M., and Prapiestiene, R.: Assessment of grain-size composition spatial structure for Lithuanian's Pleistocene surface deposits by statistical grid method, Geologija, 55, 58-65, 2006.

Wiklander, L.: The effect of lime on soil, J. Royal Swedish Academy of Agriculture and Forestry, 113, 68-78, 1986.

Yagodin, B., Derjugin, I., and Zhukov, J.: Praktikum po agrokhimii, (Practical Agrochemistry), Moskva: Agropromizdat, 1987 (in Russian). 